\title{
Biological removing of Cadmium from contaminated media by fungal biomass of Trichoderma species
}

\author{
Fariba Mohsenzadeh $^{1 *}$ and Farzad Shahrokhi ${ }^{2}$
}

\begin{abstract}
Background: Environment pollution by heavy metals is a global disaster and there are several cleaning methods including bioremediation. Trichoderma species inhibit the growth of pathogenic fungi and play a useful role in agriculture and ecosystem management.

Methods: In this study, the removing of cadmium ions by three species of Trichoderma (T. asperellum, T. harzianum and $T$. tomentosum) were studied under different $\mathrm{pH}(5,7,9)$ and different concentrations of $\mathrm{Cd}(1,100,200 \mathrm{ppm})$ in liquid media containing potato extract and dextrose. Above mentioned fungal strains were cultured in the $\mathrm{Cd}$-polluted media and the remaining amount of metal ions in the media was measured after two months growth, using atomic absorption.

Results: Results showed that all three fungal species were able to reduce the amount of $\mathrm{Cd}$ in the all three $\mathrm{pH}$ of the medias; but their removal ability varies depending on the species and cultural conditions. T. asperellum was showed maximum removal efficiency of cadmium (76.17\%), (10.75 mg/g, at fungal dry weight). Based on our results, the most removal efficiency of $\mathrm{Cd}$ ions for the fungal species was evaluated in the alkaline $\mathrm{pH}$.
\end{abstract}

Conclusions: Trichoderma species are important fungi in decreasing of Cadmium ions. They have bioremediation potency under various $\mathrm{pH}$ and concentration conditions.

Keywords: Biological removing, Cadmium, Heavy metals, Trichoderma fungi

\section{Background}

Environmental pollution with metals, semi-metals and organic contaminants is a serious problem of worldwide and contamination with heavy metals is one of the most dangerous pollutants [1]. Existence of heavy metals showed adverse effects on flora, fauna and cause to groundwater contamination through leaching. It is also causes to reduce the performance and product quality in agriculture and is dangerous for public health and other living organisms [2]. Also existence of heavy metals in the soil caused the environmental stresses that can lead to reduction of plant growth [2,3]. Heavy metals are emitted into the environment by sewage and waste materials from various resources such as metal plating,

\footnotetext{
* Correspondence: fmohsenzade@gmail.com

'Department of Biology, Faculty of Science, Bu-Ali Sina University, Hamedan, Iran

Full list of author information is available at the end of the article
}

paint industry, metallurgy, released oil ingredients in the soil, combustion of fossil fuels, mining, ores washing, pesticides, colored material, batteries, natural erosion of rocks and so on [4]. Due to the toxic effects of these compounds particularly intervention on cellular enzymatic systems, are able to impose their biological effects at the cellular level and causes to severe detrimental effects on gastrointestinal, respiratory and nervous organs and tend to cell necrosis in the exposed organs [5]. When the heavy metals accumulate in the soil, they are affected microbial activity and can also put human health at risk; because they are entered in the food chain. Toxic effects of metals appear in the various processes such as reduction of nitrogen fixation, irregularities in synthesis of enzymes and entering into food chain [6].

There are various processes to reduce concentrations of heavy metals in the environment. In this regard, it is notable that the microorganisms use these contaminants

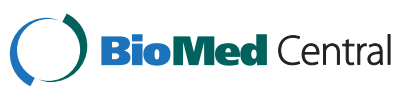


as a source of nutrients and energy and convert them into soluble substances. This process is known as bioremediation [7]. In this method, there is the possibility of removing of one or more pollutants from environment, with a low cost, and remaining products have not detrimental effects on the ecosystem of contaminated sites [3]. The using of microorganism such as algae, fungi, bacteria, and yeasts that can absorb the heavy metals, have been considered by some prior researchers for bioremediation of heavy metal polluted media $[1,8,9]$. In this way, microorganisms immobile metal ions by means of linking them with their cell walls $[10,11]$.

Selection of a biomass for using in bioremediation is very important, it should be abundance in environment and adapted to environmental conditions [12-15]. Many contaminants can be reduced by means of biological methods and some of them can be remediated by fungi [15]. In this regard, Aspergillus niger was used for remediation of silver and Talarmyces emersonii and Basidiomycetes were used for accumulation and recycling of uranium [16,17].

Some researchers were able to remove $\mathrm{Cd}, \mathrm{Ni}$ and $\mathrm{Pb}$ by biological removal using fungi with the efficiency of 94.47\% for $\mathrm{Cd}, 79.81 \%$ for $\mathrm{Ni}$ and $99.73 \%$ for $\mathrm{Pb}$ [18]. In another research, chromium and nickel uptake by resistant bacteria and fungi was studied and results showed that removal efficiency of nickel was $90 \%$ with the amount of 0.1 milligrams of fungal biomass of Aspergillus niger [19]. Also in other study, $0.7 \mathrm{~g} / \mathrm{l}$ of fungal biomass of Aspergillus niger showed $84 \%$ removal of cadmium ions [20,21].

The Trichoderma fungal species are found commonly in the all types of soils and some of them have the ability for cleaning of polluted environments and can be applied as effective microorganisms for bioremediation of pollutants [11].

Although there are several researches about bioremediation potency of fungi for $\mathrm{Cd}$, but the most used fungi, Aspergillus species for example, are pathogens or produced toxins in the media. The aim of this research is to find a fungal species with high potential of bioremediation of $\mathrm{Cd}$ in aqueous media. We are evaluated Trichoderma species that are non-parasitic and nonpathogen fungi that are useful fungi for agriculture and recycling of biomass in nature. Based on our bibliographical studies there is not any prior research about Cd bioremediation using Trichoderma species.

\section{Methods}

\section{Preparation of fungal species}

Three different fungal species belonging to the genus Trichoderma was obtained from the Laboratory of Mycology, Faculty of Agriculture, Bu-Ali Sina University. The samples were transferred to PDA (Potato Dextrose Agar) sterile media for in vitro testing use. The samples were kept in the refrigerator at $4^{\circ} \mathrm{C}$ temperature, after the fungal biomass was reached to maximal growth. These colonies are suitable for transferring to new media and were used in our experiments as resource [22].

\section{Preparation of the liquid media}

After fungal proper growth on the solid media, liquid media were prepared with the formula containing the amount of $250 \mathrm{~g} / \mathrm{l}$ potato extract, $20 \mathrm{~g} / \mathrm{l}$ of dextrose, $0.25 \mathrm{~g} / \mathrm{l}$ of tetracycline antibiotic (to prevent bacteria growth) in three $\mathrm{pH}$ $(5,7,9)$. Lactic acid and $\mathrm{KOH}(3 \%)$ were used for adjustment of the $\mathrm{pH}$ in the prepared media [23].

\section{Preparation of solutions, treatment and measurement}

In this study, at the first, the stock solution of cadmium (1000 ppm) was prepared from cadmium nitrate $(\mathrm{Cd}$ $\left.\left(\mathrm{NO}_{3}\right)_{2}, 4 \mathrm{H}_{2} \mathrm{O}\right)$ salts. Three $\mathrm{pH}$ including 5, 7, and 9, three concentrations including 1, 100, and $200 \mathrm{ppm}$, and three fungal species including Trichoderma asperellum, T. harzianum and T. tomentosum were selected for determination of optimal removing condition for cadmium. In each experiment, one the above-mentioned factors were chosen as variable and the others were kept as constant. Fungal biomass was removed from the media after two months. For this aim, the existing media were passed through the filter paper (Whatman No. 42) then they were centrifuged at $1500 \mathrm{rpm}$ for $5 \mathrm{~min}$. The debris was discarded and the supper homogeneous liquid, without fungal particles, was collected [24]. Then the remaining metal ions that exists in media, was determined using atomic absorption spectrophotometer and was compared with the metal concentration at the beginning of experiments using the statistical analysis. It is noteworthy that, all experiments were repeated in three replicates and the average was reported as the final result. After experiments, according to the metal uptake capacity, the optimal conditions were found for using in remediation of metal-contaminated environments.

\section{Determination of removal efficiency}

The following equilibrium (1) was used for determination of metal removal efficiency by the studied fungi [25].

$$
R=\left(\frac{P_{0}-P_{\mathrm{e}}}{P_{0}}\right) \times 100
$$

In this equilibrium, $\mathrm{R}$ is the percentage of metal removal by the fungal biomass, $\mathrm{P}_{0}$ is the initial concentration of metal ions (ppm) and $\mathrm{P}_{\mathrm{e}}$ is the final concentration of metal ions $(\mathrm{ppm})$ in the experimental media.

\section{Determination of removal efficiency based on the dry weight of the fungi}

To obtain the dry weight of the fungal biomass, were placed in a glass dish and was hold in the desiccator at 
$105^{\circ} \mathrm{C}$ for $48 \mathrm{~h}$. The following equilibrium (2) was used for determination of the amount of metal adsorbed per dry weight of fungi [25].

$$
q=\frac{\left(C_{i}-C_{e}\right) \times V}{M}
$$

In this equilibrium $\mathrm{q}$ is the metal absorbance based on dry weight of fungi $(\mathrm{mg} / \mathrm{g}), \mathrm{C}_{\mathrm{i}}$ is the initial concentration of metal at the beginning of experiment (ppm), $\mathrm{C}_{\mathrm{e}}$ is the metal concentration at the end of experiment ( $\mathrm{ppm}), \mathrm{V}$ is the volume of the solution (l) and $M$ is fungal dry mass (g).

\section{Statistical analysis}

In this study, independent variables are $\mathrm{pH}$ of the solution, different concentrations of cadmium and various species of the Trichoderma. The dependent variable is removal efficiency of Cadmium in each of the solution. The obtained data were analyzed using PASW (SPSS 18) software. For testing of normality and distribution of data, the Kolmogorov- Smirnov test with 95\% confidence level was used. Two-way analysis of variance, ANOVA, was used for comparing of the means of obtained results [26].

\section{Results}

\section{Effect of $\mathrm{pH}$ on $\mathrm{Cd}$ removing}

The effect of $\mathrm{pH}$ on the $\mathrm{Cd}$ removing by the studied fungi in the comparison of blank samples (controls) was investigated in this study. According to Figure 1, maximum ability for Cadmium removing was in $\mathrm{pH}=9$ in the all three Trichoderma species. The lowest removal ability was evaluated in $\mathrm{pH}=5$. In $\mathrm{pH}=7$ removal capacity was considerably high, but it was lower than that of its amount at $\mathrm{pH}=9$. The optimal removing was obtained $91.06 \%$ (10.95 mg/g based on fungus dry weight)

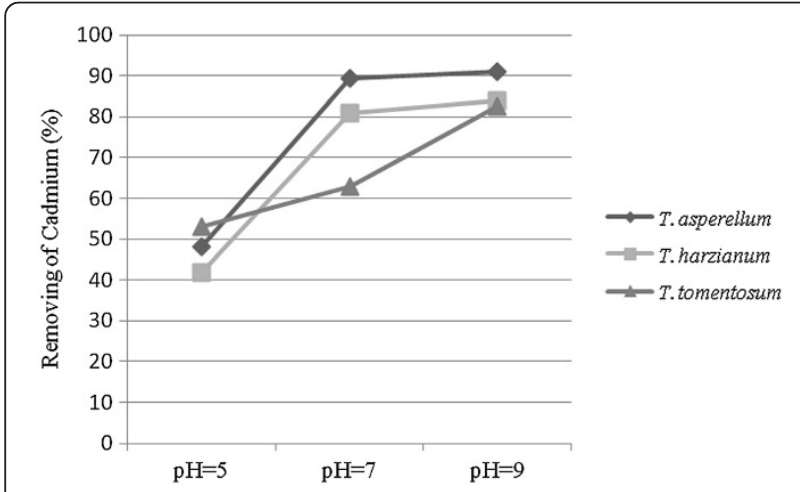

Figure 1 Effect of $\mathrm{pH}$ on the removal ability of cadmium by Trichoderma species. Maximum ability for cadmium removing was in $\mathrm{pH}=9$ for the all three Trichoderma species and the lowest removal ability was evaluated in $\mathrm{pH}=5$ for T. asperellum, $83.92 \%$ (9.85 $\mathrm{mg} / \mathrm{g}$ based on fungus dry weight) for $T$. harzianum and $82.63 \%$ (5.48 $\mathrm{mg} / \mathrm{g}$ based on fungus dry weight) for $T$. tomentosum at the $\mathrm{pH}=9$. The all above-mentioned data represented decreasing of $\mathrm{Cd}$ in the experimental samples than control ones. After the reducing of $\mathrm{pH}$ to 5 , removal ability of cadmium was decreased up to $48.14 \%$ (10.48 mg/g based on fungus dry weight) for $T$. asperellum, $41.84 \%$ (9.43 $\mathrm{mg} / \mathrm{g}$ based on fungus dry weight) for $T$. harzianum and $53.04 \%$ (5.01 mg/g based on fungus dry weight) for T. tomentosum.

\section{Effect of concentration on $\mathrm{Cd}$ accumulation}

Effect of initial concentration of $\mathrm{Cd}$ on the accumulation ability of the studied fungal species was studied. Results showed that $\mathrm{Cd}$ accumulation capacity in the fungal species was affected by its initial concentrations in the experimental media (Figure 2). According to the results, armed with the increasing initial concentrations of metal ions from $1 \mathrm{ppm}$ to $100 \mathrm{ppm}$, adsorption capacity increased and removal ability of $\mathrm{Cd}$ was increased as following: For T. asperellum was increase from $66.88 \%$ to $80.37 \%$, for $T$. harzianum increased from $40.0 \%$ to $78.35 \%$ and for $T$. tomentosum increased from $44.55 \%$ to $76.98 \%$. In the initial concentration of more than 100 ppm, the significant change in the rate of metal removing was not observed and the difference between the absorption rate in the solutions with initial concentration of $100 \mathrm{ppm}$ and $200 \mathrm{ppm}$ was not significant $(\mathrm{p} \leq 0.05)$.

\section{Comparing of the removal capacity of the Trichoderma species}

Comparing of metal removal capacity of the studied fungal species showed that there is a species-specific relationship between the fungi and $\mathrm{Cd}$ removing and then their removal ability (Figure 3 and Table 1). The results showed that Trichoderma asperellum has most ability in

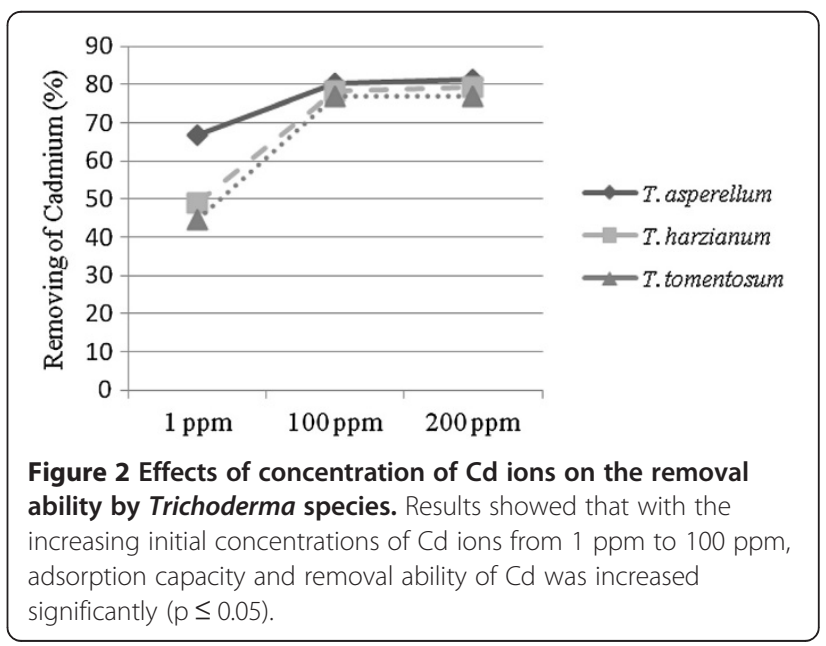




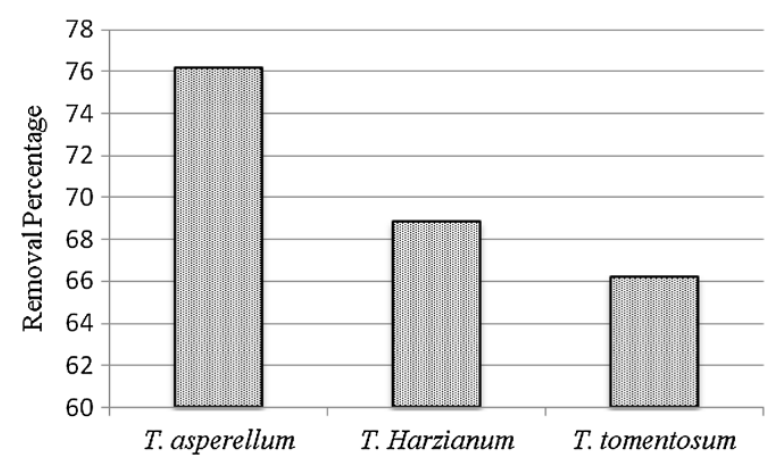

Figure 3 Effect of Trichoderma species on the removal percentage of $\mathbf{C d}$ ions. T. asperellum showed the highest ability and $T$. tomentosum showed the lowest ability in removal of $\mathrm{Cd}$ ions.

removal of cadmium ions (76.17\%), (10.75 mg/g based on fungus dry weight) and Trichoderma tomentosum has the lowest ability in removal of Cadmium ions (66.19\%), (5.23 $\mathrm{mg} / \mathrm{g}$ based on fungus dry weight).

\section{Discussion}

\section{Effect of $\mathrm{pH}$ on the $\mathrm{Cd}$ removing}

$\mathrm{pH}$ is an important factor in the biological removing process and changes of $\mathrm{pH}$, is very effective on chemical activity of metal ions that exists in solution and also absorption activity based on biomass and metal ions competition with each other [22].

In the of biological removing process, $\mathrm{pH}$ has impact two factors: first solubility of metal ions and the other total charge of the adsorbent, since the protons can be absorbed by the biomass or exert by it, in fungal case, this process depend on the functional groups on the surface of fungal cells and $\mathrm{pH}$ value of the media are effective on the balance of condition of the system [23]. The functional groups such as carboxyl, hydroxyl, amino and phosphate, on the fungal cell surfaces have major role in the uptake of $\mathrm{Cd}$ ions and they have different behavior at various $\mathrm{pH}$ conditions [24]. The effect of this factor will help us in determining the point at which biomass will maximum absorb. According to Figure 1, with increasing the amount of $\mathrm{pH}$, adsorption capacity is also was increased. It is also indicated that in the low $\mathrm{pH}$, with respect to cadmum nitrate that was used in this study, $\mathrm{Cd}$ ions are present in the form $\mathrm{Cd}^{+2}$, therefore this cations should be harder absorb to the biomass that absorbed proton and is acidified [17,27]. According to our results, the maximum absorption was evaluated at $\mathrm{pH}=9$. Similar result was reported by Das [28] about several strains of Termitomyces clypeatus in absorbing of $\mathrm{Cd}, \mathrm{Cu}$ and $\mathrm{Cr}$.

At the beginning of the experiment on the adsorption of heavy metals in aqueous solutions, increasing of $\mathrm{pH}$ is observed. This phenomenon could be justifiable according to the release of $\mathrm{H}^{+}$from the some biomass components in solution that is a kind of ion exchange between $\mathrm{H}^{+}$and metal ions. $\mathrm{pH}$ of a solution also affected by the chemical properties of the material and activity of functional groups (carboxylic, phosphate and amino) on the cell wall that they are in combination with metal ions in the desired position [29]. In general absorption behavior of various materials is similar, such as: (a) low absorption at the $\mathrm{pH}$ lower than 4 and (b) significant absorption when the $\mathrm{pH}$ of solution is in the range of 5 to 9

Table 1 P-Value and F statistic values obtained for three different Trichoderma species in the $5 \%$ significance level

\begin{tabular}{|c|c|c|c|c|c|c|c|}
\hline Species & Sources & Type III sum of squares & df & Mean square & $\mathbf{F}$ & Sig. & Partial eta squared \\
\hline \multirow[t]{5}{*}{ T. asperellum } & $\mathrm{pH}$ & 680.10624 & 2 & 340.5312 & 879.1518 & 000.0 & 994.0 \\
\hline & Concentration & 473.1169 & 2 & 737.584 & 185.167 & 000.0 & 949.0 \\
\hline & $\mathrm{pH}^{*}$ Con. & 583.23 & 4 & 896.5 & 686.1 & 197.0 & 273.0 \\
\hline & Error & 956.62 & 18 & 498.3 & & & \\
\hline & Total & 381.168578 & 27 & & & & \\
\hline \multirow[t]{5}{*}{ T. harzianum } & $\mathrm{pH}$ & 175.9919 & 2 & 588.4959 & 048.857 & 000.0 & 990.0 \\
\hline & Concentration & 715.5348 & 2 & 358.2674 & 146.462 & 000.0 & 981.0 \\
\hline & $\mathrm{pH}^{*}$ Con. & 252.680 & 4 & 063.170 & 388.29 & 000.0 & 867.0 \\
\hline & Error & 163.104 & 18 & 787.5 & & & \\
\hline & Total & 573.144214 & 27 & & & & \\
\hline \multirow[t]{5}{*}{ T. tomentosum } & $\mathrm{pH}$ & 787.4085 & 2 & 894.2042 & 455.464 & 000.0 & 981.0 \\
\hline & Concentration & 582.6322 & 2 & 291.3161 & 724.718 & 000.0 & 988.0 \\
\hline & $\mathrm{pH}^{*}$ Con. & 202.607 & 4 & 801.151 & 512.34 & 000.0 & 885.0 \\
\hline & Error & 173.79 & 18 & 398.4 & & & \\
\hline & Total & 709.129408 & 27 & & & & \\
\hline
\end{tabular}

*Interaction of $\mathrm{pH}$ and Concentration. 
[9]. Of course the metal attachment to the cell wall is affected by $\mathrm{pH}$, which is competing with other metal ions [6]. Lanouette [30] reported that in the initial concentration of $100 \mathrm{ppm}$ and $\mathrm{pH}=8$, sedimentation of Nickel hydroxide ions is visible. This deposition reduced the amount of free nickel ions for the absorption and accumulation by organisms [30]. Akhtar et al. [10] was also demonstrated that carboxylic groups that are components of the cell wall of Aspergillus niger, are sites for metal ions absorption and in the very acidic $\mathrm{pH}$ values, the total surface charge of the cell is positive and thus metal cations and protons are competing for the sites in on the cell wall and tend to metal uptake reducing.

In the higher $\mathrm{pH}$, carboxylic, phosphate and amino groups cause to increase the reaction of the metal ions, thus the effective adhesion is achieved quickly. In this $\mathrm{pH}$, metal ions can move more quickly and more active sites are ready for the reaction with microorganisms. In $\mathrm{pH}$ lower than 3, functional groups in the cell wall occupy by $\mathrm{H}^{+}$ions and limitation occurs for stand of metal ions [31]. Whereas with the increase of $\mathrm{pH}$ from 3 to 9 , more functional groups, such as carboxylic and phosphate groups, become have negative charges and thus their ability is increasing or absorption of metal ions that have a positive charge [32]. Barros et al. [21] showed that removal percentage of $\mathrm{Cd}$ was about $37 \%$ in the solution with $\mathrm{pH}=5$ by the Aspergillus niger fungal biomass, that in compared with the amount in this study (48.01\%), Trichoderma showed the better ability of metal removing in the favorable conditions regarding the initial concentration of metal ions and the suitable $\mathrm{pH}$ to absorption of heavy metals.

\section{Effect of initial concentration of $c d$ ions on metal removal capacity}

Absorption of metals by fungal biomass depends on their concentration. As is seen in the Figure 2, absorption of $\mathrm{Cd}$ ions increased by increasing of the initial concentrations and therefore the increasing the equilibrium concentration and it tend to increase the absorption force or concentration gradient [7]. After some increasing of uptake by increasing in initial concentration, absorption rate did not increased that could be due to the quickly occupation of adsorption sites (due to the high surface loading) caused by the high concentration which causes to reduce entrance of metal ions into the deep pores and thus the efficiency of absorption is reduced [4]. The similar result was reported Chergui [24] that used a kind of actinomycetes, Streptomyces rimosus, for removing of $\mathrm{Cr}, \mathrm{Cu}$ and $\mathrm{Z}$. The results showed by increasing the initial concentration more than $100 \mathrm{ppm}$, absorption rate does not increase and remained constant. This indicates that active sites become saturated on the surface of biomass.
This issue can be justified that increasing the initial concentration increased collision between the absorber and metal ions partially and increased the absorption rate and it does not affected after saturation of absorption sites [22]. Leqba [27] and Sing [22] in their studies that have done on the absorption of $\mathrm{Cu}, \mathrm{Z}$ and $\mathrm{pb}$ by Phanerochaetechrys osporium, showed that the increasing of initial concentration cause to increase the metals absorption that is due to increase of electrostatic interaction between metal ions and absorber sites.

Based on the some reports, the amount of adsorbed metal per unit mass of fungal biomass increased when the initial concentration of metal ions in solution was increased highly and it maybe a result of saturation of the active sites that leading to maximum adsorption capacity of metal ions by the biomass or due to the increase of the number of ions in competition for placement in the positions that existing in external wall of the biomass [28]. In the other words, adsorption capacity of the biomass increases with increasing of concentration of metal ions in solution [24]. In addition, increasing the concentration of metal ions causes to increase the number of collisions between metal ions and cell wall that tend to accelerate metal adsorption [7]. Results showed that, initial concentration of metal ions in $100 \mathrm{ppm}$ of metal cause to absorb $82.24 \%$ of $\mathrm{Cd}$. Some researchers [22,24] was studied the rate of $\mathrm{Cd}$ uptake by microorganism Actinomycete R 27 and results showed that the amount of adsorption was about $69 \%$. Pradhan et al. [8] was studied the absorption rate of Chromium, Nickel and Iron and results showed that Microcystis was able to adsorb these metals in the range of $70 \%$ to $80 \%$. The result of our study is accordance with the results of the above-mentioned reports. Jianlong et al. [23] was also observed $100 \%$ adsorption of Lead by the fungus Aspergillus niger at the concentration of $10 \mathrm{ppm}$. Their results indicated the high absorption of heavy metal ions by the organism, at low concentrations. Therefore, the limitation of metal ions uptake at low concentrations is less than at high concentrations of ions. With the considering the high pollution of sewage of the factories and high concentrations of water soluble metals, using the biomass of microorganisms especially the fungal biomass can be very useful for bioremediation of heavy metals [33-35].

Based on our bibliographical studies there is few report about $\mathrm{Cd}$ accumulation ability of Trichoderma species, just $T$. harzianum species [36]. Our finding data showed bioremediation ability of Trichoderma species and indicated that T. asperellum is the most effective species in removing of $\mathrm{Cd}$. The most advantage of our finding is non-pathogenic properties of the studied fungi instead of prior studied fungi, Aspergillus species, for example. 


\section{Conclusion}

Biological absorption is an effective technology for the optimal removal of heavy metals $[37,38]$. In this process, adsorption and desorption rates are very high. Simplicity of the operation cause to introduce this technique as the best methods for removing of toxic materials from environment. Trichoderma species are the terricolous fungi that showed the absorption ability of heavy metals from aqueous solutions. At higher $\mathrm{pH}$, the absorption is more and the highest absorption was in the $\mathrm{pH}=9$. At the lower $\mathrm{pH}$ competition occurs between metal cautions and $\mathrm{H}^{+}$ions to connect to the fungal cell wall and the rate of absorption was reduced. One of the advantages of absorption by fungi is high-speed absorption. The $\mathrm{pH}$ and initial concentration was also effective on metal absorption rate. Based on our results the maximum $\mathrm{Cd}$ uptake is $76.17 \%$ that is evaluated for $T$. asperellum in the optimal conditions. This is the first report for the fungus.

\section{Competing interests}

The authors declare that they have no competing interests.

\section{Authors' contributions}

FSH, is a MSc student and this manuscript was wrote based on her thesis results. He analyzed the samples and wrote initial manuscript. FM, is the supervisor of the thesis and supervised the methods and the project. She wrote the original research plan of the project and edited the manuscript Both authors read and approved the final manuscript.

\section{Acknowledgements}

The authors wish to thank Dr. Doostmorad Zafari from department of plant disease at Bu- Ali University for providing the fungal species and useful commends.

\section{Author details}

${ }^{1}$ Department of Biology, Faculty of Science, Bu-Ali Sina University, Hamedan, Iran. ${ }^{2}$ Department of Environment, Islamic Azad University, Hamedan Branch, Hamadan, Iran.

Received: 31 December 2012 Accepted: 30 June 2014 Published: 4 July 2014

\section{References}

1. Xiezhi Y, Jieming C, Ming HM: Earthworm-mycorrhiza interaction on Cd uptake and growth of ryegrass. Soil Biol Biochem 2005, 37:195-201.

2. Khosravi F, Savaghebi GH, Farah Bakhsh H: Effect of Potassium chloride on Cd uptake by colza in a polluted soil. Water Soil J 2009, 23:28-35.

3. Mohsenzade F, Chehregani A, Akbari M: Evaluation of oil removal efficiency and enzymatic activity in some fungal strains for bioremediation of petroleum-polluted soils. Iran J Environ Health Eng 2012, 9:26-34.

4. Vadkertiova R, Slavikova E: Metal tolerance of yeasts isolated from water. J Basic Microbiol 2006, 46:145-152.

5. Saberi M, Tavali A, Jafari M, Heidari M: The effect of different levels of heavy metals on seed germination and seedling growth of Atriplex lentiformis. J Range Manage 2010, 4:112-120.

6. Nwuche CO, Ugoji EO: Effect of heavy metal pollution on the soil microbial activity. J Environ Sci 2008, 5:409-414.

7. Kumar R, Bishnoi NR, Garima K: Biosorption of Chromium (VI) from aqueous solution and electroplating wastewater using fungal biomass. Chem Eng J 2008, 135:202-208.

8. Pradhan S, Singh S, Rai LC: Characterization of various functional groups present in the capsule of Microcystis and study of their role in biosorption of Fe, Ni and Cr. Bioresour Technol 2007, 98:595-601.
9. Svecova L, Svecova M, Kubal M, Guibal E: Cadmium, Lead and Mercury biosorption on waste fungal biomass isolated from fermentation industry. Sep Purif Technol 2006, 52:142-153.

10. Akhtar M, Sastry K, Mohan P: Mechanism of metal ion biosorption by fungal biomass. Biometals 1996, 9:21-28.

11. Vankar PS, Bajpai D: Phyto-remediation of Chrome-VI of tannery effluent by Trichoderma species. Desalination 2008, 222:255-262.

12. Mohsenzadeh F, Nasseri S, Mesdaghiniam A, Nabizadeh R, Zafari D, Khodakaramian G, Chehregani A: Phytoremediation of petroleumpollutedsoils: Application of Polygonum aviculare and its root-associated (penetrated) fungal strains for bioremediation of petroleum-polluted soils. Ecotoxicol Environ Saf 2010, 73:613-619.

13. Keshtkar A, Montazer MM, Khodapanah N: Usage of two and three parametric absorption isotherms for uranium uptake by yeast. $\mathrm{NuCl}$ Sci 2009, 50:1-8.

14. Kumar R, Lee JT, Cho JY: Toxic cadmium ions removal by isolated fungal strain from e-waste recycling facility. J Environ Appl Biores 2012, 1:1-4.

15. Dugal S, Gangawane M: Metal tolerance and potential of Penicillium species for use in mycoremediation. J Chem Pharm Res 2012, 4:2362-2366.

16. Aksu Z: Equilibrium and kinetic modeling of Cadmium (II) biosorption by C. vulgaris in a batch system. Purify Technol 2002, 21:285-294.

17. Wang M, Zhou Q: Single and joint toxicity of Chlorimuron-ethyl, Cadmium, and Copper acting on wheat Triticuma estivum. Ecotoxicol Environ Saf 2005, 60:169-175

18. Farzin H: The study of bacteria, fungi and other microorganisms for the treatment of heavy metals and petroleum hydrocarbons from water and environment, Proceeding of Third Natio Conf Environ Health. Kerman, Iran; 2010.

19. Amini M, Younesi $H$, Ghorbani F, Daneshi A: Biological removal of heavy metals $\mathrm{Cd}, \mathrm{Ni}$ and $\mathrm{Pb}$ in ternary mixtures of plant wastewater using fungal biomass Aspergilus niger. Proceeding of Second Conf Exhibit Environ 2008, available at: http://www.civilica.com/Paper-CEE02-CEE02_036.html.

20. Congeevaram S, Dhanarani S, Park J, Dexilin M, Thamaraiselvi K: Biosorption of Chromium and Nickel by heavy metal resistant fungal and bacterial isolates. Hazard Mater 2007, 146:270-277.

21. Barros L, Macedo G, Duarte M, Silva E, Lobato AKCL: Biosorption of Cadmium using the fungus Aspergillus niger. Braz J Chem Eng 2003, 20:229-239.

22. Sing C: Copper adsorption and removal from water by living mycelium of white-rot fungus Phanerochaete chrysosporium. Water Resour 1998, $32: 2746-2752$

23. Jianlong W, Xinmin Z, Decai D, Ding Z: Bioadsorption of Lead (II) from aqueous solution by fungal biomass of Aspergillus niger. J Biotechnol 2002, 87:273-277.

24. Chergui A: Simultaneous biosorption of $\mathrm{Cu}, \mathrm{Zn}$ and $\mathrm{Cr}$ from aqueous solution by Streptomyces rimosus biomass. Bioresour Technol 2007, 206:179-184.

25. Shorff KA, Vaidya VK: Effect of pre-treatment on biosorption on Ni (II) by dead biomass of Mucor hiemalis. Eng Life Sci 2011, 11:588-597.

26. Nasseri S, Mohsenzadeh F, Nabizadeh R, Mesdaghinia A, Chehregani A, Zafari D: Identification of petroleum resistant plants and rhizospheral fungi for phytoremediation of petroleum contaminated soils. J Jpn Petroleum Inst 2009, 52:198-204.

27. Leqba M: Biosorption of Lead, Copper, Cadmium, and Zinc ions on loofa sponge immobilized biomass of Phanerochaete chrysosporium. Miner Eng 2004, 17:217-223.

28. Das SK: Biosorption of Cadmium, Copper and Chromium by Termitomyces clypeatus. Colloids Surf 2007, 60:46-54.

29. Liu TF, Wang T, Sun C, Wang YM: Single and joint toxicity of Cypermethrin and Copper on Chinese cabbage (Pakchoi) seeds. J Hazard Mater 2009, 163:344-348.

30. Lanouette KH: Heavy Metals Removal. Chem Engin 1977, 88:73-80.

31. Guibal E, Roulph C, Lecloirec P: Uranium biosorption by filamentous fungus Mucormiehei, pH effect on mechanisms and performances of uptake. Water Resour 1992, 26:1139-1145.

32. Bai SR, Abraham TE: Studies on Chromium (VI) adsorptiondesorption using immobilized fungal biomass. Bioresour Technol 2003, 87:17-26

33. Xu X, Xia L, Huang Q, Gu J-D, Chen W: Biosorption of cadmium by metal-resistant filamentous fungus isolated from chicken manure compost. Environ Technol 2012, 2:1-10. Online published. 
34. Abdul-Talib S: Fungal Pleurotus ostreatus biosorbent for cadmium (II) removal in industrial wastewater. J Life Sci Technol 2013, 1:64-68.

35. Das SK, Shome I, Guha AK: Surface functionalization of Aspergillus versicolor mycelia: in situ fabrication of cadmium sulphide nanoparticles and removal of cadmium ions from aqueous solution. RSC Adv 2012 2:3000-3007.

36. De Freitas Lima A, Ferreira De Moura G, Barbosa De Lima MA, Mendes De Souza P, Albero Alves Da Silva C, Maria De Campos Takaki G, Elsbao Do Nascimento: Role of the morphology and polyphosphate in Trichoderma harzianum related to cadmium removal. Molecules 2011, 16:2486-2500.

37. Simonescu CM, Ferdes M: Fungal biomass for $\mathrm{Cu}$ (II) uptake from Aqueous systems. Pol J Environ Stud 2012, 6:1831-1839.

38. Vala AK, Sutariya V: Trivalent Arsenic tolerance and accumulation in two facultative marin fungi. Joundishapur J Microbio/ 2012, 5:542-545.

doi:10.1186/2052-336X-12-102

Cite this article as: Mohsenzadeh and Shahrokhi: Biological removing of Cadmium from contaminated media by fungal biomass of Trichoderma species. Journal of Environmental Health Science \& Engineering 2014 12:102.

\section{Submit your next manuscript to BioMed Central and take full advantage of:}

- Convenient online submission

- Thorough peer review

- No space constraints or color figure charges

- Immediate publication on acceptance

- Inclusion in PubMed, CAS, Scopus and Google Scholar

- Research which is freely available for redistribution 